\title{
CANCER CRISTATUS?
}

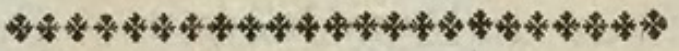

CHARACTER GENERICUS.

Pedes octo (rarius sex aut decem;) insuper manus duæ chelatæ.

Oculi duo, distantes, plurimis pedunculati ; elongati, mobiles.

Cauda articulata, inermis.

CHARACTER SPECIFICUS, ¿`c.

Cancer thorace pedibusque aculeatis, rostro porrecto bifido cristato.

Fabr, ins. 1. p. 503.

Lin. Gmel. p. 2980.

Rumph. mus. t. 8. f. 1 .

Sel. 3. t. 22. f. 2. 3.

Hujus speciei descriptionem a Seba in opus nostrum transferre non dubitavimus.

"Miratu dignissimus iste cancer, Rumphio cancer spinosissimus dictus, non tantum in tegmine superiore, quod mire gibbosum, et quasi in montes et valles distinctum est, sed in aliis quoque partibus pilosa quasi tela, et pungentes aculeos, manipulatim compositos, ostentat. Caput, veluti turritum, acuminatum, spinosis processibus undique asperum est. 
Brachia itidem crassa, longa, ramos, in omni ambitu, ramorumque propagines emittunt. Quin vel ipsi forcipes similibus undique horrent. Octo postici pedes, pari modo constituti, aculeis crassis, pungentibus, simplicibus, ubique pleni sunt. Sic et cauda sese habet plurimis brevibusque articulis geniculata. Pedes posteriores in minutum et brevem terminantur unguiculum. Color dilute griseus per omnia regnat." Maria incolit Asiatica. 


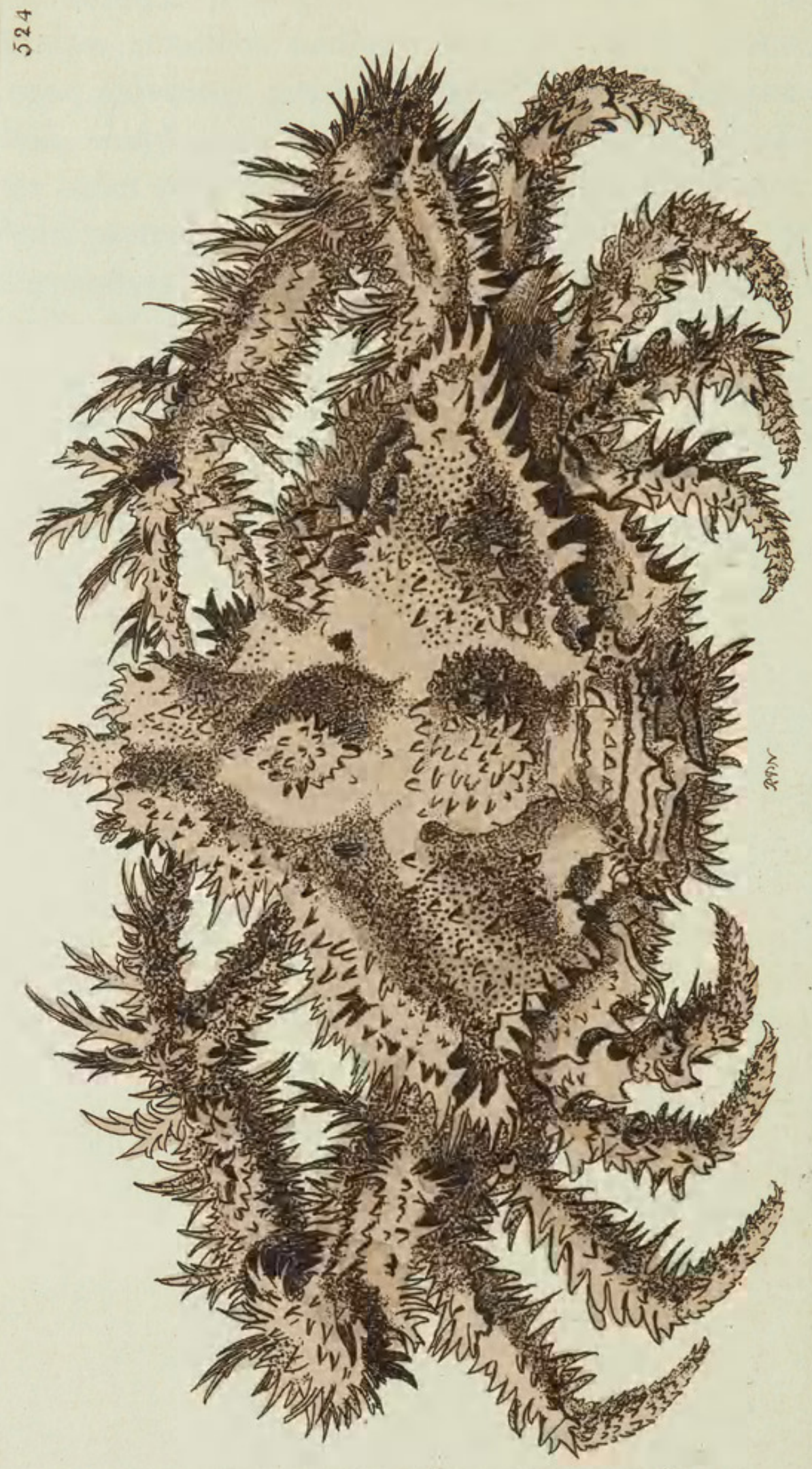




\section{CRESTED CRAB.}

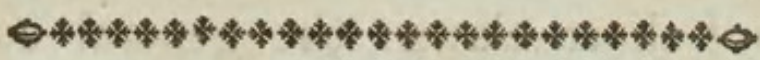

GENERIC ChARACTER.

Leg's generally eight, (in some species six or ten, besides two claspers or chelated arms. Eyes two, commonly distant; footstalked, moveable.

Tail articulated.

SPECIFIC CHARACTER, Eृ.

Short-tailed tuberculated CRAB with numerous ramified and fasciculated spines, and bifid crested snout.

This highly singular species, says Seba, is the cancer horridus of Rumphius, and is covered not only on the upper part of the body, which is very convex and marked into various elevations and depressions, but also on every other part with groupes of sharp spines and hair-like prickles: the head is elevated, acuminated, and every where beset with spiny processes : the long and thick arms are covered along their whole outline with branching subdivisions which are visible even on the forcipes themselves: the eight hind legs are formed on a similar plan, 
plan, but are covered with thick, sharp, simple spines: the tail, which is spiny also, consists of several small and short joints: the hind feet terminate in minute and short claws: the general colour of the whole animal is pale grey. It is a native of the Asiatic seas. 


\section{$2 \mathrm{BHL}$ Biodiversity Heritage Library}

Shaw, George. 1801. "The Crested Crab, Cancer cristatus [PI. 524]." The Naturalist's Miscellany 13(CXLVII), https://doi.org/10.5962/p.310970.

View This Item Online: https://www.biodiversitylibrary.org/item/281546

DOI: https://doi.org/10.5962/p.310970

Permalink: https://www.biodiversitylibrary.org/partpdf/310970

\section{Holding Institution}

Museums Victoria

\section{Sponsored by}

Atlas of Living Australia

\section{Copyright \& Reuse}

Copyright Status: Public domain. The BHL considers that this work is no longer under copyright protection.

This document was created from content at the Biodiversity Heritage Library, the world's largest open access digital library for biodiversity literature and archives. Visit BHL at https://www.biodiversitylibrary.org. 